\title{
ASUHAN KEBIDANAN PADA NY. S KEHAMILAN TRIMESTER II DENGAN HIPERTENSI GESTASIONAL
}

\author{
Eka Sarofah Ningsih* \\ *Dosen Program Studi Diploma III Kebidanan Universitas Islam Lamongan
}

\begin{abstract}
ABSTRAK
Kehamilan adalah masa dimulai dari hasil konsepsi sampai lahirnya janin dengan lama kehamilan 280 hari (40 minggu atau 9 bulan 7 hari) dihitung dari hari pertama haid terakhir. Hipertensi pada kehamilan adalah hipertensi yang timbul sebelum usia kehamilan 20 minggu tanpa disertai proteinuria. Hipertensi merupakan komplikasi yang disebabkan oleh kondisi lingkungan seperti faktor keturunan, emosi dan pola hidup yang tidak seimbang. Oleh karena itu penelitian ini bertujuan untuk mendapatkan gambaran nyata tentang teori dan praktik lapangan dalam mengembangkan pola pikir dalam melaksanakan asuhan kebidanan dengan menggunakan manajemen kebidanan.

Metode yang digunakan dalam penyusunan laporan penelitian ini adalah deskriptif yaitu metode yang dilakukan dengan tujuan memberi gambaran tentang suatu keadaan secara obyektif dengan menggunakan studi kasus yaitu perbandingan antara teori dan kasus nyata.

Berdasarkan data yang di peroleh dari Dinas Kesehatan Jawa Timur bulan Januari - Juni Tahun 2015 di dapatkan ibu hamil dengan hipertensi 11.056 orang, data dari Dinas Kesehatan Kabupaten Lamongan sebanyak 143 orang. Data yang diperoleh dari register kunjungan pemeriksaan Antenatal Care (ANC) di Puskesmas Sukodadi bulan Januari - Juli Tahun 2015 terdapat 389 orang ibu hamil, di dapatkan 6 orang $(1,5 \%)$ dengan hipertensi. di BPS Luluk Pusparini, AMd. Keb, didapatkan 2 orang $(7,7 \%)$ dengan kehamilan hipertensi.

Berdasarkan dari hasil pengkajian maka dapat ditegakkan diagnosa yaitu Asuhan Kebidanan pada Ny. S Trimester II dengan hipertensi gestasional. Dan dari hasil penelitian ini tidak terdapat kesenjangan antara tinjauan teori dan tinjauan kasus.

Diharapkan bagi petugas kesehatan hendaknya dapat mengenali tanda dan gejala hipertensi sehingga dapat melakukan penatalaksanaan dengan baik dan sesuai standart kompetensi.
\end{abstract}

Kata Kunci : Kehamilan, Trimester II, Hipertensi

\section{PENDAHULUAN}

Kehamilan adalah masa di mulai dari hasil konsepsi sampai lahirnya janin dengan lama kehamilan 280 hari (40 minggu atau 9 bulan 7 hari) dihitung dari hari pertama haid terakhir. Kehamilan di samping suatu proses reproduksi yang perlu perawatan khusus agar dapat berlangsung dengan baik, kehamilan mengandung resiko terhadap ibu maupun janin. Resiko kehamilan ini bersifat dinamis karena ibu hamil yang semula normal secara tiba-tiba dapat beresiko tinggi. Salah satunya adalah kehamilan dengan hipertensi atau di sebut juga dengan hipertensi gestasional (Depkes RI, 2002). 
Hipertensi dalam kehamilan berarti bahwa wanita telah menderita hipertensi sebelum hamil, disebut juga sebagai pre-eklamsi tidak murni. Superimposed pre-eklamsi bila disertai dengan proteinuria dan edema. Oleh karena itu setiap kehamilan dapat berkembang menjadi masalah atau komplikasi setiap saat, itu sebabnya mengapa ibu hamil memerlukan pemantauan selama kehamilannya agar dapat ditanggulangi segala masalah yang timbul, maka fokus utama asuhan antenatal care adalah mencegah terjadinya hipertensi pada kehamilan sehingga komplikasi dapat ditekan serendah mungkin yang berarti juga penekanan terhadap angka kematian ibu dan janin. (Saifudin, 2002 : 90).

Kehamilan dengan hipertensi ini dirasa sangat memprihatinkan karena dengan seketika bisa menyebabkan mortalitas dan morbiditas pada wanita yang melahirkan.. Hipertensi dapat tersebar di berbagai daerah baik yang didaerah pelosok maupun yang dekat dengan fasilitas kesehatan juga dapat mengalami hal ini.

Berdasarkan data yang di peroleh dari Dinas Kesehatan Jawa Timur tahun 2015 di dapatkan ibu hamil sebanyak 427.085 orang, dengan hipertensi 11.056 orang. Sedangkan data dari Dinas Kesehatan Kabupaten Lamongan pada tahun 2016 terdapat 17.002 orang ibu hamil dengan kehamilan hipertensi sebanyak 143 orang (Sumber: bidang layanan kesehatan kabupaten Lamongan).

Data yang diperoleh dari register kunjungan pemeriksaan Antenatal Care (ANC) di Puskesmas Sukodadi Tahun 2016 terdapat 389 orang ibu hamil, di dapatkan 6 orang $(1,5 \%)$ dengan hipertensi. di BPS
Luluk Pusparini, AMd. Keb, Ds. Sumberaji, Kec. Sukodadi, Kab. Lamongan mulai Tanggal 01 Januari s/d 31 Desember 2015 di dapatkan kunjungan ibu hamil untuk ANC sebanyak 26 orang di dapatkan 2 orang $(7,7 \%)$ dengan kehamilan hipertensi.

Penyebab hipertensi dalam kehamilan dapat diklasifikasikan sebagai hipertensi primer dan hipertensi sekunder. Hipertensi primer didefinisikan sebagai hipertensi yang tidak disebabkan oleh adanya gangguan organ lain seperti ginjal dan jantung. Hipertensi ini dapat disebabkan oleh kondisi lingkungan seperti faktor keturunan, pola hidup yang tidak seimbang, stres, dan pekerjaan. Serta sikap yang dapat menyebabkan hipertensi seperti mengkonsumsi tinggi lemak, garam, aktivitas yang rendah.

Sedangkan hipertensi sekunder di sebabkan oleh gangguan ginjal, endokrin, dan kekakuan dari aorta. Namun sebagian besar penyebab utama hipertensi dalam kehamilan adalah hiepertensi esensial. Hipertensi esensial merupakan penyakit hipertensi yang mungkin disebabkan oleh faktor heriditer serta dipengaruhi oleh faktor emosi dan lingkungan (Abdul Bari, 2002)

Wanita hamil dengan hipertensi tidak menunjukkan gejalagejala lain kecuali hipertensi. Yang paling banyak dijumpai adalah hipertensi esensial jinak dengan tekanan darah sekitar 140/90 sampai 160/100. Hipertensi jarang berubah menjadi ganas secara mendadak hingga mencapai sistolik $200 \mathrm{mmHg}$ atau lebih. Kehamilan yang disertai hipertensi esensial sewaktu-waktu dapat berubah menjadi pre-eklamsi tidak murni (super imposed) bila 
disertai dengan proteinuria dan oedem dampaknya terhadap kehamilan dan persalinannya pun sangat buruk. Dampaknya terhadap kehamilan bisa timbul sakit kepala terus menerus, pandangan kabur, mual, muntah, sesak nafas, lemah, letih lesu (pre eklamsi berat) dalam persalinan akan terjadi perdarahan dan kejang, serta dampak terhadap janin bisa menyebabkan abortus, janin mati dalam kandungan, dan pertumbuhan janin menjadi terhambat (Abdul Bari, 2006)

Pada kasus ini dampak terhadap kehamilan bisa timbul sakit kepala terus menerus, pandangan kabur, mual, muntah, sesak nafas, lemah, letih, lesu (Pre eklampsi berat) serta dampak terhadap janin bisa menyebabkan janin mati dalam kandungan dan pertumbuhan janin menjadi terhambat. Hipertensi disebabkan oleh obesitas, stres, kelebihan garam, iskemia ginjal.

Untuk mencegahnya bidan harus melakukan pengawasan secara ketat, dan lakukan kolaborasi dengan dokter SpOG dalam menurunkan tekanan darah. Sehingga tidak terjadi perubahan yang mencolok. Penanganannya yaitu dianjurkan mentaati pemeriksaan antenatal yang teratur dan jika perlu dikonsultasikan kepada ahli; dianjurkan cukup istirahat menjauhi emosi dan jangan bekerja terlalu berat; penambahan berat badan yang agresif harus dicegah. Dianjurkan untuk diet tinggi protein, rendah hidrat arang, rendah lemak dan rendah garam; pengawasan terhadap janin harus lebih teliti, disamping pemeriksaan biasa, dapat dilakukan pemeriksaan USG. Apabila tekanan darah dapat diberikan obat-obatan seperti anti hipertensif seperti serpasil, katapres, minipres dan sebagainya. (Manuaba, 2005)

Terkait dengan permasalahan yang muncul maka diperlukan asuhan kebidanan yang bersifat komprehensif dan dapat memberikan pelayanan yang paripurna baik itu meliputi aspek promotif, preventif, kuratif dan rehabilitatif. Hal ini harus dilakukan secara terpadu, kesinambungan serta memandang iklim sebagai satu kesatuan yang utuh secara biopsikososial dan spiritual dengan menekankan upaya keselamatan melalui metode pendekatan dan pemecahan masalah.

Berdasarkan data yang diperoleh di atas maka penulis tertarik untuk melakukan penelitian dengan judul "Asuhan Kebidanan Pada Ny. "S" Kehamilan Trimester II dengan Hipertensi Gestasional di BPS Luluk Pusparini, AMd.Keb. Ds. Sumberaji, Kec. Sukodadi, Kab.Lamongan Tahun 2015".

\section{TUJUAN}

Untuk mendapatkan gambaran nyata tentang teori dan praktik lapangan dalam mengembangkan pola pikir dalam melaksanakan asuhan kebidanan dengan menggunakan manajemen kebidanan pada Asuhan Kebidanan pada Ny. "S" Kehamilan Trimester II dengan Hipertensi Gestasional di BPS Luluk Pusparini, AMd.Keb. Ds. Sumberaji, Kec. Sukodadi, Kab.Lamongan.

\section{PEMBAHASAN}

Pembahasan merupakan bagian dari studi kasus yang berisi uraian secara mendalam tentang perbedaan atau kesenjangan antara tinjauan pustaka dengan tinjauan kasus yang terjadi selama penulis melaksanakan Asuhan Kebidanan 
Pada Ny. "S" GIII $P_{20002}$ Trimester II dengan Hipertensi. Untuk memudahkan dalam tinjauan ini penulis mengelompokkan permasalahan sesuai dengan langkah-langkah manajemen 7 langkah Hellen Varney (Hellen Varney, 2002)

\section{Pengkajian Data \\ Data Subjektif}

Data subjektif adalah data yang diperoleh dari wawancara langsung kepada klien dan keluarga yang meliputi identitas, keluhan utama, riwayat penyakit sekarang, riwayat kesehatan yang lalu, riwayat kesehatan keluarga, polaa kebiasaan sehari-hari (pola nutrisi, pola eliminasi, pola aktivitas, pola personal hygiene, pola istirahat), data psikologis dan data sosial budaya.

Pada tinjauan pustaka didapatkan biodata klien dan keluhan yang menyebabkan klien datang ke pelayanan kesehatan karena merasa kesehatannya terganggu. Beberapa keluhan yang terjadi pada klien antara lain, klien merasa pusing, susah tidur dan mata berkunangkunang (Manuaba, 2005).

Pada tinjauan kasus didapatkan biodata yang berisi klien datang ke pelayanan kesehatan karena klien merasa pusing. Pada langkah pertama data subyektif tidak ada kesenjangan antara tinjauan teori dan tinjauan kasus karena keluhan yang disebutkan klien pada tinjauan kasus sama dengan apa yang ada di tinjauan pustaka.

\section{Data Objektif}

Data objektif adalah data yang diperoleh melalui pemeriksaan fisik berupa inspeksi, palpasi, auskultasi, dan perkusi serta pemeriksaan penunjang.

Pada tinjauan pustaka didapatkan TTV : tensi : >140/90 mmHg, nadi : 76 - 92x/menit, suhu : $36,5-37,5^{\circ} \mathrm{C}, \mathrm{RR}: 16-24 \mathrm{x} / \mathrm{menit}$, palpasi : Leopold I : TFU pertengahan sympisis - pusat, teraba ballotement, leopold II : belum dikaji, leopold III : belum dikaji, leopold IV : belum dikaji. Pada auskultasi terdengar DJJ (+) 120 160x/menit menggunakan doppler (Saminem, 2009).

Pada tinjauan kasus, didapatkan TTV : tensi : 160/100 mmHg, nadi : 84x/menit, suhu : 37 ${ }^{\circ} \mathrm{C}, \mathrm{RR}:$ 20x/menit. Palpasi leopold I : TFU pertengahan sympisis - pusat $(16 \mathrm{~cm})$, teraba ballotement, leopold II : belum dikaji, leopold III : belum dikaji, leopold IV : belum dikaji. Auskultasi terdengar DJJ (+) 130x/menit dengan doppler. Jadi pada tinjauan kasus ini tidak ditemukan kesenjangan antara tinjauan pustaka dan tinjauan kasus. Karena pada pengkajian seluruh hasil pemeriksaan pasien sesuai dengan tinjauan pustaka.

\section{Identifikasi Diagnosa, Masalah dan Kebutuhan}

Pada tinjauan pustaka terdapat 1 diagnosa dan 2 masalah. Diagnosa tersebut adalah hipertensi sedangkan masalahnya pusing, dan susah tidur (Wiknjosastro Hanifa, 2005)

Pada tinjauan kasus dari data subyektif dan obyektif didapatkan 1 diagnosa yaitu Ny. "S" GIII $\mathrm{P}_{20002}$ Trimester II dengan hipertensi dan masalahnya pusing. Jadi antara tinjauan pustaka dan tinjauan kasus tidak ada kesenjangan. Karena pasien pada kasus ini tekanan darahnya 160/100 $\mathrm{mmHg}$ dan hal 
inilah yang menyebabkan pasien pusing.

\section{Antisipasi Masalah Potensial}

$\begin{array}{rrr}\text { Pada tinjauan } & \text { pustaka } \\ \text { ditemukan antisipasi masalah }\end{array}$
potensial yang dapat terjadi pada kehamilan dengan hipertensi pada ibu hamil berpotensial terjadi pre eklamsi. Sedangkan pada janinnya berpotensial terjadi kematian janin dalam kandungan (Jensen Bobak, 2004). Pada tinjauan kasus berdasarkan data subyektif dan obyektif yang telah dikaji penulis mengangkat masalah potensial yaitu hipertensi pada ibu hamil berpotensial terjadi pre eklamsi dan karacunan kehamilan Jadi pada langkah ketiga tidak ditemukan adanya kesenjangan antara tinjauan pustaka dan tinjauan kasus.

\section{Identifikasi Kebutuhan Segera}

Pada tinjauan pustaka kebutuhan tindakan segera akan dilakukan apabila terjadi kegawat daruratan adalah kolaborasi dengan dokter spesialis dalam penurunan tekanan darah (Patrucia Pooter, 2005). Sedangkan pada tinjauan kasus dilakukan kolaborasi dengan dokter spesialis. Jadi antara tinjauan pustaka dan tinjauan kasus tidak terjadi kesenjangan karena pada tinjauan kasus juga dilakukan kolaborasi dengan dokter spesialis.

\section{Intervensi}

Merupakan pelaksanaan rencana asuhan menyeluruh yang di tentukan dari langkah-langhkah sebelumnya, berdasarkan tujuan dan kriteria yang diharapkan intervensi disusun berdasarkan diagnosa yang timbul (Nursalam, 2003).

Pada tinjauan teori intervensi atau rencana yang dilakukan pada pasien dengan hipertensi antara lain beritahu pada pasien tentang hasil pemeriksaan, jelaskan tanda bahaya pada ibu hamil trimester II, jelaskan tanda bahaya hipertensi pada ibu hamil, anjurkan ibu untuk menjaga personal hygiene, anjurkan ibu untuk mengkonsumsi makanan dengan gizi yang seimbang, anjurkan ibu untuk menghindari makanan yang mengandung tinggi garam dan tinggi lemak, anjurkan ibu untuk istirahat cukup, anjurkan ibu untuk minum multivitamin, anjurkan ibu untuk kontrol ulang 1 minggu lagi atau sewaktu - waktu jika ada keluhan, jelaskan penyebab pusing yang dialami oleh ibu, anjurkan ibu untuk istirahat cukup dan teratur, anjurkan ibu untuk tidur miring kiri (Manuaba, 2005).

Sedangkan pada tinjauan kasus intervensi yang dilakukan pada pasien dengan hipertensi antara lain beritahu pada pasien tentang hasil pemeriksaan, jelaskan tanda bahaya pada ibu hamil trimester II, jelaskan tanda bahaya hipertensi pada ibu hamil, anjurkan ibu untuk menjaga personal hygiene, anjurkan ibu untuk mengkonsumsi makanan dengan gizi yang seimbang, anjurkan ibu untuk menghindari makanan yang mengandung tinggi garam dan tinggi lemak, anjurkan ibu untuk istirahat cukup, anjurkan ibu untuk minum multivitamin (caviplex), anjurkan ibu untuk kontrol ulang 1 minggu lagi atau sewaktu - waktu jika ada keluhan, jelaskan penyebab pusing yang dialami oleh ibu, anjurkan ibu untuk istirahat cukup dan teratur, anjurkan ibu untuk tidur miring kiri.

Berdasarkan data dari tinjauan teori dan kasus nyata tidak terdapat kesenjangan. Meskipun demikian Asuhan kebidanan yang disusun telah disesuaikan dengan masalah 
yang ditemukan pada penulis, dimana perencanaan pada tinjauan kasus tidak jauh berbeda dengan tinjauan teori.

\section{Implementasi}

Merupakan

pelaksanaan

rencana asuhan yang menyeluruh, pada tinjauan kasus implementasi yang dilakukan (Hellen Varney, 2002)

Pada tinjauan teori implementasi yang dilakukan pada pasien dengan hipertensi antara lain memberitahukan pada pasien dan keluarga tentang hasil pemeriksaan, menjelaskan tanda bahaya pada ibu hamil trimester II, menjelaskan tanda bahaya hipertensi pada ibu hamil, ,menganjurkan ibu untuk menjaga personal hygiene, menganjurkan ibu untuk mengkonsumsi makanan dengan gizi yang seimbang, menganjurkan ibu ntuk menghindari makanan yang mengandung tiggi garam dan tinggi lemak, menganjurkan ibu untuk istirahat cukup, menganjurkan ibu untuk minum tablet $\mathrm{Fe}$ dan multivitamin, menganjurkan ibu untuk kontrol ulang 1 minggu lagi atau sewaktu waktu jika ada keluhan, menjelaskan penyebab pusing yang dialami oleh ibu, menganjurkan ibu untuk istirahat cukup dan teratur, menganjurkan ibu untuk tidur miring kiri (Manuaba, 2005).

Sedangkan pada tinjauan kasus implementasi yang dilakukan pada pasien dengan hipertensi antara lain memberitahukan pada pasien dan keluarga tentang hasil pemeriksaan, menjelaskan tanda bahaya pada ibu hamil trimester II, menjelaskan tanda bahaya hipertensi pada ibu hamil, menganjurkan ibu untuk menjaga personal hygiene, menganjurkan ibu untuk mengkonsumsi makanan dengan gizi yang seimbang, menganjurkan ibu ntuk menghindari makanan yang mengandung tiggi garam dan tinggi lemak, menganjurkan ibu untuk istirahat cukup, menganjurkan ibu untuk minum multivitamin (caviplex), menganjurkan ibu untuk kontrol ulang 1 minggu lagi atau sewaktu waktu jika ada keluhan, menjelaskan penyebab pusing yang dialami oleh ibu, menganjurkan ibu untuk istirahat cukup dan teratur, menganjurkan ibu untuk tidur miring kiri

Berdasarkan data dari tinjauan teori dan kasus nyata tidak terdapat kesenjangan. Meskipun demikian Asuhan kebidanan yang disusun telah disesuaikan dengan masalah yang ditemukan pada penulis, dimana pelaksanaan pada tinjauan kasus tidak jauh berbeda dengan tinjauan teori.

\section{Evaluasi}

Evaluasi dilakukan untuk mengetahui keaktifan asuhan yang sudah diberikan apakah benar-benar telah terpenuhi sesuai dengan kriteria hasil yang ditentukan dalam perencanaan pada tinjauan kasus. Langkah evaluasi merupakan penilaian dan pelaksanaan sesuai dengan kriteria hasil dan alokasi waktu yang telah diberikan. Keberhasilan evaluasi bergantung pada kerjasama antara pasien, keluarga, petugas serta sarana dan prasarana yang tersedia juga penatalaksanaan asuhan kebidanan yang sesuai dengan standar kebidanan (Harni Koesno, 2006).

Evaluasi didapatkan diagnosa GIII $\mathrm{P}_{20002}$ Trimester II dengan hipertensi. Pasien mengerti dan memahami penjelasan yang diberikan oleh petugas mengenai 
keadaannya dan ibu mau melaksanakan anjuran yang di berikan oleh petugas. Dalam hal ini tidak ditemukan kesenjangan antara tinjauan pustaka dan tinjauan kasus.

$$
\text { Pada evaluasi catatan }
$$

perkembangan I didapatkan diagnosa GIII $\mathrm{P}_{20002}$ Trimester II dengan Hipertensi. Dengan kriteria hasil tekanan darah berkurang. Pada data subyektif pasien dalam keadaan sehat dan tidak ada keluhan. Pada data obyektif keadaan umum pasien baik, TTV : tensi : 130/90 mmHg, suhu : $36,5^{\circ} \mathrm{C}$, nadi : $80 \mathrm{x} / \mathrm{menit}$, RR : $20 \mathrm{x} /$ menit. Dalam hal ini tidak ditemukan kesenjangan antara tinjauan pustaka dengan tinjauan kasus karena adanya kesesuaian antara tinjauan teori dan tinjauan kasus.

\section{KESIMPULAN}

Dalam proses pengumpulan data melalui pengkajian yang merupakan langkah awal untuk mendapatkan data klien yang berupa data subyektif yang diperoleh melalui wawancara dengan klien dan keluarga klien. Sedangkan data obyektif di peroleh melalui pemeriksaan fisik, baik inspeksi, palpasi, perkusi, auskultasi, pemeriksaan penunjang, pemeriksaan panggul luar (Hellen Varney, 2002). Hasil pemeriksaan pada Ny. "S" GIII P $\mathrm{P}_{20002}$ Trimester II dengn Hipertensi adalah keadaan umum cukup, postur tubuh tegak, cara berjalan tegak, Raut wajah cemas, TB : $155 \mathrm{~cm}$, berat badan : $64 \mathrm{~kg}$, LILA : $28 \mathrm{~cm}$, tensi: 160/100 $\mathrm{mmHg}$, nadi : $84 \mathrm{x} /$ menit, suhu : $37{ }^{\circ} \mathrm{C}$, RR : $20 \mathrm{x} /$ menit, pada pemeriksaan fisik didapatkan konjungtiva tidak pucat, sklera putih, tidak ada tarikan intercosta, Leopold I : TFU pertengahan sympisis - pusat (16 $\mathrm{cm})$, teraba balotement (+). Leopold II : belum dikaji. Leopold III : belum dikaji. Leopold IV : belum dikaji, DJJ (+) $130 \mathrm{x} /$ menit (doppler), reflek patella $(+/+)$.

Berdasarkan data subyektif dan data obyektif yang ada maka diagnosa yang di temukan adalah $\mathrm{Ny}$ "S" GIII $\mathrm{P}_{20002}$ Trimester II dengan Hipertensi, dan masalah yang di dapat adalah pusing.

\begin{tabular}{llr}
\multicolumn{1}{c}{ Pada } & antisipasi masalah \\
potensial & yang dilakukan
\end{tabular}
berdasarkan adanya data yang mendukung masalah potensial yang mungkin timbul adalah berpotensial terjadi pre-eklamsia. Identifikasi kebutuhan segeranya adalah kolaborasi dengan Dokter spesialis dalam penurunan tekanan darah dan pencegahan kenaikan berat badan yang berlebihan.

Dengan intervensi terutama asuhan kebidanan yang disusun di sesuaikan dengan Asuhan Kebidanan dengan hipertensi, sehingga dapat dilakukan asuhan kebidanan yang mengacu pada tinjauan dan kriteria hasil yang akan dilaksanakan.

Pada pelaksanaan asuhan kebidanan pada Ny "S" GIII $\mathrm{P}_{20002}$ Trimester II dengan Hipertensi, mengacu pada rencana yang telah ditetapkan dan semua intervensi dapat dilaksanakan karena adanya kerjasama yang baik antara petugas kesehatan, pasien, dan keluarga. Setelah dilakukan asuhan kebidanan pada $\mathrm{Ny} \mathrm{P}_{20002}$ dengan hipertensi selama 2 kali kunjungan, didapatkan hasil hipertensi telah teratasi.

\section{Saran}

Diharapkan institusi menambah fasilitas yang lebih canggih seperti internet sehingga mahasiswa dapat mendapatkan informasi baru yang lebih cepat. 


\begin{abstract}
Diharapkan petugas lahan praktek dapat membimbing mahasiswa sehingga mahasiswa dapat pengalaman yang nyata dalam melakukan asuhan kebidanan terutama pada ibu hamil dengan hipertensi.

Dengan mendapatkan pengalaman diharapkan dapat menerapkan apa yang telah didapat dalam perkuliahan dengan kasus nyata dalam melakukan asuhan kebidanan dengan menggunakan manajemen Hellen Varney.

Diharapkan klien lebih kooperatif dalam segala tindakan sehingga mencapai hasil akhir yang optimal tanpa adanya komplikasi.
\end{abstract}

\section{PUSTAKA}

Bobak Lowdermik, Jensen. 2004. Buku Ajar Keperawatan Maternitas Edisi 4. Jakarta; EGC.

Dep.Kes. RI., 2002. Paket Informasi Program Safe Motherhood. di Indonesia. Jakarta : Dep.Kes. RI.

Dinkes Jatim. 2015. Data Demografi Kesehatan Kabupaten Lamongan. Jatim : Bidang Layanan Kesehatan Kabupaten Lamongan.

Hanifa, Wiknjosastro, 2005. Ilmu Kebidanan Edisi 3. Jakarta; YBP-SP.

Harni Koesno. MKM. 2006. Standar Pelayanan Kebidanan

Manuaba, Ida Bagus. 2005. Ilmu Kebidanan Penyakit Kandungan dan Keluarga Berencana Untuk Pendidikan Bidan. Jakarta: EGS.
Nursalam. 2003. Konsep dan Penerapan Metodologi Penelitian Ilmu Keperawatan. Jakarta : Salemba Medika.

Patrucia Pooter A. 2005. Buku Ajar Fundamental Keperawatan . Jakarta : Salemba Medika.

Saifuddin Abdul Bari, dkk. 2002. Buku Acuan Nasional Pelayanan Kesehatan Maternal dan Neonatal. Jakarta; Yayasan Bina Pustaka Sarwono Prawirohardjo.

Saifuddin Abdul Bari. 2006. Buku Acuan Nasional Pelayanan Kesehatan Maternal dan Neonatal. Jakarta; YBP-SP.

Saminem, Hajjah, 2009. Kehamilan Normal : Seri Asuhan Kebidanan. Jakarta : EGC.

Varney Hellen. 2002. Buku Saku Bidan. Jakarta; EGC. 